\title{
WANPRESTASI DALAM AKAD PEMBIAYAAN IJARAH MULTIJASA (Analisis Putusan Pengadilan Agama Purbalingga No. 1721/Pdt.G/2013/PA.Pbg)
}

\author{
Mulya Lazwardi \\ Magister Kenotariatan Fakultas Hukum Universitas Narotama \\ Lasuardimulya900@gmail.com
}

\begin{abstract}
This article is Legal Research using statute approach, conceptual approach and case approac. Result of this legal research is characteristics of multi-service ijarah financing, that the purpose of ijarah is to take advantage with a replacement road. Associated with the Islamic banking system as part of the Islamic economic concept, therefore sharia banking is not only required to generate profit through every commercial transaction, but also demanded to implement sharia values in accordance with the Qur'an and Hadith. Breach of contract crtiertia on multi-service ijarah financing and settlement efforts is each party must meet the obligations arising from the contract. If one does not fulfill the obligations in the contract, settlement of wanprestasi in sharia banking withm mediation or through BASYARNAS.
\end{abstract}

Keywords : breach of contract, financing agreement, ijarah, multi services.

\begin{abstract}
Abstrak
Artikel ini merupakan penelitian hukum yang menggunakan pendekatan perundang-undangan, pendekatan konsep dan pendekatan kasus. Hasil penelitian menunjukkan bahwa karakteristik pembiayaan ijarah multi jasa adalah mengambil manfaat dengan jalan pengganti. Dikaitkan dengan sistem perbankan syariah sebagai bagian dari konsep ekonomi Islam, maka tidak hanya dituntut untuk menghasilkan keuntungan melalui setiap transaksi komersial saja. Akan tetapi, juga dituntut untuk mengimplementasikan nilai-nilai syariah yang sesuai dengan Al - Qur’an dan Hadist. Kriteria wanprestasi pada pembiayaan ijarah multi jasa dan upaya penyelesaiannya adalah masing-masing pihak harus memenuhi kewajiban yang timbul dari akad. Apabila salah satu tidak memenuhi kewajiban dalam akad, penyelesaian wanprestasi dalam perbankan syariah dengan mediasi atau melalui BASYARNAS.
\end{abstract}

Kata Kunci : wanprestasi, akad pembiayaan, ijarah, multi jasa.

Pendahuluan

Perbankan syariah telah banyak masyarakat yang mengenalnya, namun masih banyak pula yang belum memahami kiprah dari perbankan syariah. Perbankan adalah segala sesuatu yang menyangkut tentang Bank Syariah dan Unit 
Usaha Syariah, mencakup kelembagaan, kegiatan usaha, serta cara dan proses dalam melaksanakan kegiatan usahanya (Pasal 1 angka 1 UU Nomor 21 Tahun 2008 tentang Bank Syariah).

Perbankan syariah menjalankan usaha dengan berpedoman pada syariat Islam, nampak dari semakin gencarnya media baik cetak maupun elektronik secara masif menginformasikan mengenai Bank Syariah. Eksistensi Bank Syariah di Indonesia, mayoritas penduduk beragama Islam, sepantasnya bila segala keinginan masyarakat yang bersentuhan dengan kegiatan usaha sesuai dengan syariah Islam sehingga menjadikan Bank Syariah menjadi kokoh. Hal ini didukung oleh fatwa Majelis Ulama Indonesia (MUI), yang isinya menyatakan bunga bank adalah riba dan hukumnya adalah haram, maka khususnya para nasabah yang beragama Islam mencari alternatif bank lain yang dalam menjalankan usahanya tidak menerapkan bunga. Bank yang dimaksud adalah Bank Syariah, yang memberikan modal tidak didasarkan pada akad pemberian kredit melainkan didasarkan pada akad pembiayaan.

Perbankan syariah sebagaimana perbankan konvensional, dalam menjalankan kegiatan usaha menanggung risiko sesuai dengan salah satu kaidah Islam yaitu "keuntungan adalah bagi pihak yang menanggung risiko." Bank Islam menolak bunga sebagai biaya untuk penggunaan uang dan pinjaman sebagai alat investasi. Dalam melaksanakan investasinya, Bank Syariah memberi keyakinan bahwa dana mereka sendiri (equity), serta dana lain yang tersedia untuk investasi, mendatangkan pendapatan yang sesuai dengan syariah dan bermanfaat bagi masyarakat.

Keberadaan bank syariah dikenal sejak tahun 1992 dengan diundangkannya Undang Undang Nomor 7 Tahun 1992 tentang Perbankan yang kemudian diubah dengan Undang - Undang Nomor 10 Tahun 1998 tentang Perubahan Atas Undang - Undang Nomor 7 Tahun 1992 Tentang Perbankan. UU Perbankan memberikan landasan hukum atas keberadaan bank syariah di Indonesia bahwa dalam undang - 
undang tersebut ditetapkan sistem perbankan Indonesia yaitu dual banking system, sistem yang menerapkan bahwa bank konvensional dapat beroperasi secara syariah dengan jalan membuka unit usaha syariah secara utuh maupun dengan jalan konversi dari sistem konvesional ke sistem syariah sedangkan bank syariah sendiri tidak diperkenankan untuk beroperasi secara konvensional. Namun, tidak hanya undang - undang tersebut yang menjadi dasar operasional bagi bank syariah karena juga terdapat regulasi Bank Indonesia sebagai otoritas moneter dan fatwa-fatwa Dewan Syariah Nasional yang mendasari segala produk dan operasional bank syariah sebagaimana Penjelasan Umum UU Bank Indonesia.

Bank syariah
menjalankan kegiatan usaha
pemberian pembiayaan, di antaranya
mudharabah berdasarkan Pasal 20
angka 4 Kompilasi Hukum Ekonomi
Syariah (KHES) adalah kerjasama
antara pemilik dana atau penanam
modal dengan pengelola modal
untuk melakukan usaha tertentu
dengan pembagian keuntungan

berdasarkan nisbah. Berdasarkan Pasal 20 angka 5 KHES Muzaraah adalah kerjasama antara pemilik lahan dengan penggarap untuk memanfaatkan lahan. Berdasarkan Pasal 20 angka 6 KHES Murabahah adalah pembiayaan saling menguntungkan yang dilakukan oleh shahib al-mal dengan pihak yang membutuhkan melalui transaksi jual beli dengan penjelasan bahwa harga pengadaan barang dan harga jual terdapat nilai lebih yang merupakan keuntungan atau laba bagi shahib almal dan pengembaliannya dilakukan secara tunai atau angsur. Ijarah berdasarkan Pasal 1 angka 9 KHES adalah sewa barang dalam jangka waktu tertentu dengan pembayaran.

Sementara itu, dalam Pasal 1 angka 12 UU Bank Syariah telah dirumuskan pula pengertian prinsip syariah yaitu "Prinsip syariah adalah prinsip hukum Islam dalam kegiatan perbankan berdasarkan fatwa yang dikeluarkan oleh lembaga yang memiliki kewenangan dalam penetapan fatwa di bidang syariah."

Dalam ketentuan Pasal 2 Peraturan Bank Indonesia Nomor 10/16/PBI/ 2008 Tentang Perubahan 
Atas Peraturan Bank Indonesia Nomor 9/19/PBI/2007 Tentang Pelaksanaan Prinsip Syariah Dalam Kegiatan Penghimpunan Dana dan Penyaluran Dana Serta Pelayanan Jasa Bank Syariah (PBI Nomor 10/16/PBI/ 2008) ditegaskan bahwa kegiatan usaha penghimpunan dana, penyaluran dana dan pelayanan jasa bank berdasarkan prinsip Syariah yang dilakukan oleh Bank merupakan jasa perbankan. Dalam melaksanakan jasa perbankan melalui kegiatan penghimpunan dana, penyaluran dana dan pelayanan jasa bank, bank wajib menjalankan usahanya berdasarkan Prinsip Syariah. Pemenuhan Prinsip Syariah dilaksanakan dengan memenuhi ketentuan pokok hukum Islam antara lain prinsip keadilan dan keseimbangan ('adl wa tawazun), kemaslahatan (maslahah), dan universalisme (alamiyah) serta tidak mengandung gharar, maysir, riba, zalim dan objek haram.

Pemenuhan Prinsip Syariah dilakukan dalam kegiatan penghimpunan dana dengan menggunakan akad Wadi'ah dan Mudharabah serta dalam kegiatan penyaluran dana berupa pembiayaan dengan mempergunakan antara lain akad mudharabah, musyarakah, murabahah, salam, istishna, ijarah, ijarah muntahiya bitamlik, dan qardh.

Prinsip syariah yang wajib dipenuhi oleh bank syariah dimaksud adalah sebagaimana Pasal 3 UU Bank Syariah bahwa perbankan Syariah bertujuan menunjang pelaksanaan pembangunan nasional dalam rangka meningkatkan keadilan, kebersamaan, dan pemerataan kesejahteraan rakyat. Prinsip Universalisme (alamiyah) yaitu dapat dilakukan oleh, dengan, dan untuk semua pihak yang berkepentingan (stakeholder) tanpa membedakan agama, ras, dan golongan, sesuai dengan semangat kerahmatan semesta (rahmatan lil alamin) (Usman, 2009 : 19).

Di dalam pelaksanaannya akad pembiayaan ini timbul permasalahan ketika penerima akad tidak mampu memenuhi kewajibannya atau dikenal dengan wanprestasi. Berdasarkan Pasal 36 KHES menentukan bahwa pihak dapat dianggap melakukan ingkar janji apabila karena 
kesalahannya: tidak melakukan apa yang dijanjikan untuk melakukannya; melaksanakan apa yang dijanjikannya, tetapi tidak sebagaimana dijanjikan; melakukan apa yang dijanjikannya, tetapi terlambat; atau melakukan sesuatu yang menurut perjanjian tidak boleh dilakukan.

Dibahasnya mengenai akad ijarah, ada kaitannya dengan kasus penerima pembiayaan Ijarah Multi Jasa sebesar Rp 200.000,.000, (dua ratus juta) untuk jangka waktu 5 tahun guna pengembangan/ pembiayaan usaha di bidang penerbitan Tabloid ASPIRASI. Tawaran tersebut diterima dengan catatan, bahwa debitur yang memiliki 4 ruko yang siap dijual sehingga kalau ruko tersebut terjual, maka semua hutang akan dibayar lunas. Debitur menyampaikan kepada Bank, sekaligus mempersilahkan Bank Perkreditan Rakyat Syariah (BPRS) untuk ikut menawarkan dan menjualnya. Kenyataannya Debitur tidak mampu membayar pembiayaan ijarah multi guna yang dibuat dalam akta No. 01, dan Bank Syariah tidak mengambil tindakan untuk menjual ruko tersebut bahkan tiba - tiba menyatakan debitur wanprestasi serta bank syariah menyita barang - barang milik debitur berupa barang tetap yang telah diikat Hak Tanggungan Nomor : 02754/2011.

Tindakan Bank Syariah menyita barang-barang tetap tersebut debitur merasa keberatan, menyatakan bank tidak sesuai dengan janjinya bersedia untuk menawarkan ruko sebagai pelunasan utang. Penyelesaian secara damai tidak membawa hasil, bank menggugat debitur ke Pengadilan Agama Purbalingga atas dasar wanprestasi. Pengadilan Agama Purbalingga dalam putusannya Nomor: 1721/Pdt.G/2013/ PA.Pbg., amarnya menyatakan: Tergugat cidera janji/ wanprestasi terhadap Akad Pembiayaan Ijarah Multi Jasa Nomor: 01 tanggal 13 September 2011 yang merugikan Penggugat, yaitu berupa kerugian materiil sebesar Rp 252.393.450.-(dua ratus lima puluh dua juta tiga ratus sembilan puluh tiga ribu empat ratus lima puluh rupiah). Menghukum Tergugat membayar kerugian materiil sebesar Rp 252.393.450.- 
(dua ratus lima puluh dua juta tiga ratus sembilan puluh tiga ribu empat ratus lima puluh rupiah) kepada Penggugat langsung seketika setelah putusan mempunyai kekuatan hukum tetap. Berdasarkan uraian sebagaimana tersebut di atas, maka yang dipermasalahkan adalah (1) Karakteristik pembiayaan ijarah multi jasa dan (2) Kriteria wanprestasi pada pembiayaan ijarah multi jasa dan upaya penyelesaiannya.

\section{Metode Penelitian}

Penelitian ini merupakan penelitian hukum yang menggunakan pendekatan perundang-undangan (statute approach), pendekatan konseptual (conceptual approach) dan pendekatan kasus (case approach) (Marzuki, 2006 : 93). Pendekatan perundang-undangan (statute approach) dilakukan dengan menelaah semua undang-undang yang bersangkut paut dengan isu hukum yang sedang dibahas yaitu pembiayaan Ijarah. Conseptual approach yaitu pendekatan didasarkan atas sumber hukum berupa pendapat para sarjana dan yurisprudensi. Sedangkan Case approach, yaitu pendekatan dengan menganalisis kasus yang telah diputus oleh pengadilan dan putusannya telah mempunyai kekuatan hukum tetap atau inkracht.

Sumber - sumber penelitian hukum dapat dibedakan menjadi sumber-sumber penelitian yang berupa bahan - bahan hukum primer dan bahan - bahan hukum sekunder. Bahan - bahan hukum primer terdiri dari perundang - undangan dalam hal ini UU Perbankan, UU Perbankan Syariah, Burgerlijk Wetboek, PBI, catatan-catatan resmi atau risalah dalam pembuatan perundangundangan dan putusan-putusan hakim. Sedangkan bahan-bahan sekunder berupa semua publikasi tentang hukum yang bukan merupakan dokumen-dokumen resmi. Publikasi tentang hukum meliputi buku - buku teks, kamus kamus hukum, jurnal - jurnal hukum, dan komentar - komentar atas putusan pengadilan.

\section{Hasil dan Pembahasan}

\section{Karakteristik Pembiayaan Ijarah Multi Jasa}

Di dalam Perbankan Syariah dikenal adanya agunan atau jaminan, 
baik berupa benda bergerak maupun benda tidak bergerak, yang diserahkan oleh pemilik Agunan kepada Bank Syariah dan/atau UUS, guna menjamin pelunasan kewajiban nasabah penerima fasilitas. Mengenai bank syariah, dikemukakan oleh Muhammad Syafi i Anthonio sebagai berikut bahwa sejak awal kelahiran, perbankan syariah dilandasi dengan kehadiran dua gerakan renaissance Islam modern: neorevivalis dan modern. Tujuan utama dari pendirian lembaga keuangan berlandaskan etika ini adalah tiada lain sebagai upaya kaum muslimin untuk mendasari segenap aspek kehidupan ekonominya berdasarkan Al Qur`an dan As-Sunnah (Antonio, $2001:$ 18).

Oleh karena, kelahiran bank syariah didasarkan atas Al Qur`an dan As-Sunnah, berarti dasar operasional dari Bank Syariah adalah berbeda dengan bank konvensional. Mengenai perbedaan pokoknya adalah terletak pada sistem operasionalnya, dijelaskan oleh Suhrawardi Bank konvensional sistem operasinya didasarkan kepada bunga. Orang yang menanamkan uangnya pada bank motifnya antara lain untuk mendapatkan bunga, sedangkan pada
Bank Syariah pemilik modal menanamkan uangnya pada bank tidak untuk mendapatkan bunga. Akan tetapi, dalam rangka mendapatkan keuntungan dengan jalan bagi hasil. Modal yang ditanamkan oleh nasabah pada bank tersebut kemudian oleh bank disalurkan kepada mereka-mereka yang membutuhkan (sebagai modal dalam usaha). Penyaluran tersebut diadakan dengan akad bahwa keuntungan yang diperoleh dari usaha tersebut akan dibagi sesuai kesepakatan (Suhrawardi, 2000 : 48 $-49)$.

Dengan demikian Bank Syariah yang memberikan modal tersebut bukan didasarkan atas pinjam meminjam melainkan didasarkan atas akad pembiayaan dengan bagi keuntungan atau bagi hasil. Pembiayaan menurut pasal 1 angka 25 UU Perbankan Syariah adalah penyediaan dana atau tagihan yang dipersamakan dengan itu berupa :

a) Transaksi bagi hasil dalam bentuk mudharabah dan musyarakah;

b) Transaksi sewa-menyewa dalam bentuk ijarah atau sewa beli 
dalam bentuk ijarah muntahiya bittamlik;

c) Transaksi jual beli dalam bentuk piutang murabahah, salam, dan istishna';

d) Transaksi pinjam meminjam dalam bentuk piutang qardh; dan

e) Transaksi sewa-menyewa jasa dalam bentuk jjarah untuk transaksi multijasa berdasarkan persetujuan atau kesepakatan antara Bank Syariah dan/atau UUS dan pihak lain yang mewajibkan pihak yang dibiayai dan/atau diberi fasilitas dana untuk mengembalikan dana tersebut setelah jangka waktu tertentu dengan imbalan ujrah, tanpa imbalan, atau bagi hasil.

Prinsip pembiayaan syariah, pada intinya dibedakan dalam 4 (empat) jenis, yaitu :

(1) Prinsip Bagi Hasil (Profit and Loss Sharing).

Secara umum dapat dilakukan dalam empat akad utama, yaitu :

a) Al-Musyarakah (Partnership, Project Financing Participation)

b) Al-Jual beli (Trust Financing, Trust Investment) c) Al-Muzara'ah (Harvest-Yield Profit Sharing)

d) Al-Musaqah (Plantation Management Fee Based On Certain Portion of

(2) Prinsip Jual Beli (Sale and Purchase). Ada tiga jenis jual beli yang dikembangkan sebagai sandaran pokok dalam pembiayaan Bank Syariah, yaitu

a) Al-Murabahah (Deffered Payment Sale)

b) As - Salam (In-front Payment Sale)

c) Al - Istishna' (Purchase By Order or Manufacture)

(3) Prinsip Sewa (Lease).Terbagi dalam dua jenis :

a) Al-Ijarah

(Operational Lease)

b) Al-Ijarah Al-Muntahia BitTamlik (Financial Lease with Purchase Option)

(4) Prinsip Jasa (Fee-Based Services). Pembiayaan dalam bentuk Al- Qardh (Soft and Benevolent Loan) Pemberian modal pembiayaan yang berdasarkan atas Syariat Islam dengan tujuan: 
a) Mengarahkan kegiatan ekonomi umat untuk bermu`amalah secara Islam, khususnya mu`amalah yang berhubungan dengan perbankan, agar terhindar dari praktik-praktik riba atau jenis-jenis usaha lain yang mengandung unsur gharar (tipuan), di mana jenis-jenis usaha tersebut selain dilarang dalam Islam juga telah menimbulkan dampak negatif terhadap ekonomi umat;

b) Untuk menciptakan suatu keadilan di bidang ekonomi, dengan jalan meratakan pendapatan melalui kegiatan investasi, agar tidak terjadi kesenjangan yang amat besar antara pemilik modal (orang kaya) dengan pihak yang membutuhkan modal (orang miskin);

c) Untuk meningkatkan kualitas hidup umat, dengan jalan membuka peluang berusaha yang lebih besar terutama kepada kelompok miskin, yang diarahkan kepada kegiatan usaha yang produktif, menuju terciptanya kemandirian berusaha (berwira usaha);

d) Untuk membantu menanggulangi

(mengentaskan) masalah kemiskinan, yang pada umumnya merupakan program utama dari negara-negara yang sedang berkembang. Upaya bank Islam dalam mengentaskan kemiskinan ini berupa pembinaan nasabah yang lebih menonjol sifat kebersamaan dari siklus usaha yang lengkap seperti program pembinaan pengusaha produsen, pembinaan pedagang perantara, program pengem-bangan modal kerja dan program pengembangan usaha bersama;

e) Untuk menjaga kestabilan ekonomi/moneter pemerintah. Dengan aktivitas-aktivitas bank Islam yang diharapkan mampu menghindarkan inflasi akibat penerapan sistem bunga, menghindarkan persaingan yang tidak sehat antara lembaga keuangan, khususnya bank dan menanggulangi 


kemandirian lembaga
keuangan, khususnya bank dari
pengaruh gejolak moneter baik
dari dalam maupun luar negeri;
Untuk menyelamatkan
ketergantungan umat Islam
terhadap bank non Islam
(konvensional)
menyebabkan umat Islam
berada di bawah kekuasaan
bank, sehingga umat Islam
tidak bisa melaksanakan
ajaran agamanya secara
penuh, terutama di bidang
kegiatan bisnis
perekonomian (Sumitro, 2002
: 17 - 18).

Bank syariah yang berbeda dengan bank konvensional, maka bank syariah mempunyai karakteristik yang berbeda dengan bank konvensional. Perihal karakteristik perbankan syariah, Abd Shomad mengemukakan bahwa sistem perbankan syariah sebagai bagian dari konsep ekonomi Islam (Shomad, 2012 : 201). Oleh karena itu, perbankan syariah tidak hanya dituntut untuk menghasilkan keuntungan melalui setiap transaksi komersial saja, tetapi juga dituntut untuk mengimplementasikan nilai nilai syariah yang sesuai dengan AlQur`an dan Hadist. Hal ini berbeda dengan bank konvensional yang mengedepankan transaksi ekonomi yang bermotif untuk mendapatkan keuntungan, maka dalam perbankan syariah dalam menjalankan kegiatan usaha lebih mengedepankan pada prinsip ekonomi syariah yang lebih mengedepankan nilai-nilai AlQur`an dan Hadist. Perbankan syariah atau Islam merupakan bagian dari ekonomi Islam, yang sarat dengan nilai keagamaan dan pembiayaan Islam adalah prinsip Tauhid, atau Keesaan Tuhan karena ekonomi Islam merupakan kegiatan berkaitan dengan hubungan antara sesama manusia, maka pembiayaan Islam juga harus mengacu kepada ketentuan bermuammalah yang ada dalam Al Qur'an sebagai kalam Allah SWT dan Hadist Nabi Besar Muhammad SAW.

Kegiatan usaha perbankan syariah dikenal adanya asas saling menguntungkan maksudnya setiap yang dilakukan oleh bank dan nasabah harus bersifat 
menguntungkan semua pihak yang berakad, tidak boleh menguntungkan salah satu pihak dan merugikan pihak lain. Dijumpai dalam ayat $\mathrm{Al}$ Qur'an menyebutkan mengenai 'keuntungan'. Salah satu ayat menyatakan bahwa perolehan keuntungan dari perniagaan adalah halal. Allah SWT berfirman kepada orang-orang beriman agar berjalan dan berdagang dengan cara yang saling menguntungkan (QS 4 : 33). Dalam perspektif itu, keuntungan tidak dilihat dari segi uang secara an sich, 'keuntungan' bisnis adalah apabila bisnis yang dilakukan itu bersifat amal atau kebajikan, atau yang didasarkan pada kebenaran, yang dimulai dengan niat yang benar, dalam melakukan bisnis itu, kualitas manusianya semakin baik atau dapat lebih dipercaya, dapat menambah ilmu dan wawasan yang lebih luas sehingga memperbaiki kemampuan yang ada, dan menambah silahturahmi atau persaudaraan antara sesama.

Karakteristik perbankan syariah juga pada transaksi ekonomi syariah. Berdasarkan KDPPLKS (Kerangka Dasar Penyusunan dan Penyajian
Laporan Keuangan Syariah) paragraf 15 diatur tentang asas transaksi syariah yang pada dasarnya menganut prinsip (Usman, 2009 : 19)

1) Persaudaraan (Ukhuwah);

2) Keadilan ('adalah);

3) Riba;

4) Zalim;

5) Maasyir;

6) Gharar;

7) Haram;

8) Kemaslahatan;

9) Keseimbangan;

10) Universalisme.

Bank hanya memberikan pembiayaan jika mempunyai keyakinan atas kemampuan dan kesanggupan debitur dalam mengembalikan pinjamannya, salah satu aspek yang digunakan sebagai pertimbangan bank adalah menganjurkan debitur menyerahkan barang miliknya yang diikat sebagai jaminan pembiayaan. Jaminan menurut UU Perbankan tahun 1967 diartikan sebagai agunan. Sedangkan jaminan menurut UU Perbankan diartikan sebagai keyakinan atas itikad dan kemampuan serta 
kesanggupan nasabah debitur untuk melunasi utangnya atau mengembalikan pembiayaan dimaksud sesuai dengan yang diperjanjikan. Dengan demikian jaminan yang dimaksud adalah itikad dan kemampuan serta kesanggupan debitur dalam mengembalikan pinjamannya, jika pihak kreditor ragu-ragu terhadap itikad dan kemampuan serta kesanggupan debitur dalam mengembalikan pinjamannya, berarti baik selaku kreditor meragukan itikad dan kemampuan serta kesanggupan debitur.

Pembiayaan Al-ijarah berasal dari kata al-ajru, yang berarti al-iwadhu (ganti). Menurut pengertian syara, alijarah adalah suatu jenis akad untuk mengambil manfaat dengan jalan pengganti. Al- ijarah adalah akad pemindahan hak guna atas barang atau jasa melalui pembayaran upah sewa, tanpa diikuti dengan pemindahan kepemilikan (ownership/milkiyyah) atas barang itu sendiri (Muhammad, 2008 : 327). Menurut Fatwa Dewan Syarah Nasional No.27/DSN/MUI/III/ 2002 bahwa akad al-Ijarah al-Muntahiyah bi al-
Tamlik boleh dilakukan dengan ketentuan:

1) Semua rukun dan syarat yang berlaku dalam akad Ijarah (Fatwa DSN Nomor 09/DSNMUI/IV/2000) berlaku pula dalam akad al-Ijarah al-Muntahiyah bi al-Tamlik. Perjanjian untuk melakukan akad al-Ijarah alMuntahiyah bi al-Tamlik harus disepakati ketika akad Ijarah ditandatangani. Hak dan kewajiban setiap pihak harus dijelaskan dalam akad;

2) Ketentuan tentang al-Ijarah alMuntahiyah bi al-Tamlik. Pihak yang melakukan al-Ijarah alMuntahiah bi al-Tamlik harus melaksanakan akad Ijarah terlebih dahulu. Akad pemindahan kepemilikan, baik dengan jual beli atau pemberian, hanya dapat dilakukan setelah masa Ijarah selesai. Janji pemindahan kepemilikan yang disepakati di awal akad Ijarah adalah wa'd, yang hukumnya tidak mengikat. Apabila janji itu ingin dilaksanakan, maka harus ada akad pemindahan kepemilikan 
yang dilakukan setelah masa Ijarah selesai.

3) Jika salah satu pihak tidak menunaikan kewajibannya atau jika terjadi perselisihan di antara kedua belah pihak, maka penyelesaiannya dilakukan melalui Badan Arbitrase Syari'ah setelah tidak tercapai kesepakatan melalui musyawarah. Syarat ijarah yang harus ada agar terpenuhi ketentuan-ketentuan hukum Islam adalah sebagai berikut :

a) Jasa atau manfaat yang akan diberikan oleh aset yang disewakan tersebut harus tertentu dan diketahui dengan jelas oleh kedua belah pihak.

b) Kepemilikan aset tetap pada yang menyewakan yang bertanggung jawab pemeliharaannya, sehingga aset tersebut harus dapat memberi manfaat kepada penyewa.

Akad ijarah dihentikan pada saat aset yang bersangkutan berhenti memberikan manfaat kepada penyewa. Jika aset tersebut rusak dalam periode kontrak, akad ijarah masih tetap berlaku. Ijarah manfaat (Al-Ijarah ala al-Manfa'ah), bahwa ijarah manfaat berhubungan dengan sewa jasa, yaitu memperkerjakan jasa seseorang dengan upah sebagai imbalan jasa yang disewa. Pihak yang mempekerjakan disebut musta'jir, pihak pekerja disebut ajir, upah yang dibayarkan disebut ujrah misalnya, sewa menyewa rumah, kendaraan, pakaian dll (Ascarya, 2011 : 99). Dalam hal ini mu'jir mempunyai benda-benda tertentu dan musta'jir butuh benda tersebut dan terjadi kesepakatan antara keduanya di mana mu'jir mendapatkan imbalan tertentu dari musta'jir dan musta'jir mendapatkan manfaat dari benda tersebut (Afandi, 2009 : 187 - 188).

Ijarah yang bersifat pekerjaan (Al-Ijarah ala Al-Amal), bahwa berhubungan dengan sewa aset atau properti, yaitu memindahkan hak untuk memakai dari aset atau properti tertentu kepada orang lain dengan imbalan biaya sewa. Bentuk ijarah mirip leasing (sewa) di bisnis konvensional artinya ijarah berusaha mempekerjakan seseorang untuk melakukan sesuatu (Ascarya, 2011 : 
99). Mu'jir adalah orang yang mempunyai keahlian, tenaga, jasa dan lainnya, kemudian musta'jir adalah pihak yang membutuhkan keahlian, tenaga atau jasa tersebut dengan imbalan tertentu. Mu'jir mendapatkan upah (ujrah) atas tenaga yang ia keluarkan untuk musta'jir dan musta'jir mendapatkan tenaga atau jasa dari mu'jir (Afandi, 2009 : 187 - 188). Contohnya yang mengikat bersifat pribadi adalah menggaji seorang pembantu rumah tangga, sedangkan yang bersifat serikat, yaitu sekelompok orang yang menjual jasanya untuk kepentingan orang banyak. (Seperti; buruh bangunan, tukang jahit, buruh pabrik, dan tukang sepatu (Dahlan, $2008: 662-663)$.

Ijarah bentuk pertama banyak diterapkan dalam pelayanan jasa perbankan syari'ah, sedangkan ijarah bentuk kedua biasa dipakai sebagai bentuk investasi atau pembiayaan di perbankan syari'ah. Selain dua jenis pembagian di atas, dalam akad ijarah juga ada yang dikenal dengan namanya akad alijarah muntahiya bit tamlik (sewa beli), yaitu transaksi sewa beli dengan perjanjian untuk menjual atau menghibahkan objek sewa di akhir periode sehingga transaksi ini diakhiri dengan alih kepemilikan objek sewa (Dahlan, 2008 : 662 663).

Dalam akad ini musta'jir samasama dapat mempergunakan obyek sewa untuk selamanya. Akan tetapi keduanya terdapat perbedaan. Perbedaan tersebut ada dalam akad yang dilakukan di awal perjanjian. Oleh karena, akad ini sejenis perpaduan antara akad jual beli dan akad sewa, atau lebih tepatnya akad sewa yang diakhiri dengan kepemilikan penyewa atas barang yang disewa melalui akad yang dilaksanakan kedua belah pihak (Afandi, 2009 : 187 - 188).

\section{Kriteria Wanprestasi Pada Pembiayaan Ijarah Multi Jasa Dan Upaya Penyelesaiannya}

Pada akad ijarah jika nasabah penyewa barang tidak kewajiban dalam akad maka dikatakan telah ingkar janji atau wanprestasi dalam pembiayaan ijarah disebut Ta'widh/ganti rugi adalah penggantian atas kerugian riil yang dibayarkan oleh pihak yang 
melakukan wanprestasi sebagaimana Pasal 1 angka 38 KHES Syariah. Wanprestasi menurut Abdulkadir Muhammad diartikan sebagai berikut: "Tidak memenuhi kewajiban yang telah ditetapkan dalam perikatan" (Muhammad, 2004 : 20).

Menurut Subekti, seseorang dikatakan telah wanprestasi apabila :

a) Tidak melakukan apa yang disanggupi akan dilakukannya;

b) Melaksanakan apa yang dijanjikannya, tetapi tidak sebagaimana dijanjikan;

c) Melakukan apa yang dijanjikannya tetapi terlambat (Subekti, 2004 : 45).

Pendapat Subekti tersebut sesuai dengan Pasal 36 KHES Syariah bahwa pihak dapat dianggap melakukan ingkar janji, apabila karena kesalahannya :

a) Tidak melakukan apa yang dijanjikan untuk melakukannya;

b) Melaksanakan apa yang dijanjikannya, tetapi tidak sebagaimana dijanjikan;

c) Melakukan apa yang dijanjikannya, tetapi terlambat; atau d) Melakukan sesuatu yang menurut perjanjian tidak boleh dilakukan.

Hal ini berarti bahwa unsur dari wanprestasi adalah bahwa perbuatan yang dilakukan oleh debitur dapat disesalkan, karena dengan perbuatan tersebut dapat berakibat merugikan orang lain dan pelaku harus dapat dimintakan pertanggungjawaban atas perbuatan yang dilakukannya tersebut. Di atas telah disebutkan bahwa salah satu unsur wanprestasi adalah berakibat merugikan orang lain. Hal ini sesuai dengan yang dikemukakan oleh Yahya Harahap sebagai berikut: "Jika wanprestasi itu benar-benar menimbulkan kerugian kepada kreditur, maka debitur wajib mengganti kerugian yang timbul. Namun untuk itu harus ada hubungan sebab akibat atau kausal verband antara wanprestasi dengan kerugian" (Harahap, 1998 : 65).

Dengan demikian seseorang yang wanprestasi memberikan hak kepada pihak lain yang dirugikannya untuk menggugat ganti kerugian. Mengenai bentuk ganti kerugian dapat berupa penggantian biaya, rugi dan bunga, sesuai dengan ketentuan 
Pasal 1243 BW bahwa penggantian biaya, rugi dan bunga karena tidak dipenuhinya suatu perikatan barulah mulai diwajibkan apabila si berutang, setelah dinyatakan lalai memenuhi perikatannya tetap melalaikannya atau jika sesuatu yang harus diberikan atas dibuatnya hanya dapat diberikan atau dibuat dalam tenggang waktu yang telah dilampaukannya. Hal ini berarti bahwa seseorang dikatakan wanprestasi jika tidak memenuhi kewajiban sebagaimana yang ditetapkan dalam perjanjian. Jika tidak ditentukan waktu pemenuhan prestasinya, maka setelah diberitahukan pemenuhan prestasi, namun tetap melalaikannya. Di dalam Pasal 37 KHES disebutkan bahwa pihak dalam akad melakukan ingkar janji, apabila dengan surat perintah atau dengan sebuah akta sejenis itu telah dinyatakan ingkar janji atau demi perjanjiannya sendiri menetapkan, bahwa pihak dalam akad harus dianggap ingkar janji dengan lewatnya waktu yang ditentukan. Maksud ketentuan Pasal 1243 BW jo Pasal 37 KHES adalah jika dalam akad murabahah tidak ditentukan waktu berprestasi, maka penerima modal pembiayaan dikatakan wanprestasi apabila telah dikirimkan surat pemberitahuan akan berprestasi.

Adanya wanprestasi, berarti timbul suatu sengketa untuk diselesaikan. Adapun syarat-syarat yang wajib dipenuhi dalam hal pengajuan penyelesaian sengketa melalui mediasi perbankan, adalah sebagai berikut :

a) Diajukan secara tertulis dengan disertai dokumen pendukung yang memadai;

b) Pernah diajukan upaya penyelesaiannya oleh nasabah kepada bank;

c) Sengketa yang diajukan tidak sedang dalam proses atau belum pernah diputus oleh lembaga arbitrase atau peradilan, atau belum terdapat kesepakatan yang difasilitasi oleh lembaga mediasi lainnya;

d) Sengketa yang diajukan merupakan sengketa keperdataan;

e) Sengketa yang diajukan belum pernah diproses dalam mediasi perbankan yang difasilitasi oleh bank indonesia; 
f) Pengajuan penyelesaian sengketa tidak melebihi 60 (enam puluh) hari kerja sejak tanggal surat hasil penyelesaian pengaduan yang disdampaikan bank kepada nasabah.

Proses mediasi baru akan dilaksanakan setelah nasabah atau perwakilan nasabah dan bank menandatangani perjanjian mediasi (agreement to mediate), yang didalamnya memuat kesepaktan untuk memilih mediasi sebagai alternatif penyelesaian sengketa serta persetujuan untuk patuh dan tunduk pada aturan mediasi yang ditetapkan oleh Bank Indonesia.

Pelaksanaan proses mediasi sampai ditandatanganinya akta kesepakatan dilakukan dalam jangka waktu paling lama 30 (tiga puluh) hari kerja sejak nasabah atau perwakilan nasabah dan bank menandatangani perjanjian mediasi (agreement to mediate). Ketentuan mengenai jangka waktu ini tidak mutlak, artinya berdasarkan kesepakatan para pihak jangka waktu yang ada dapat diperpanjang sampai dengan 30 (tiga puluh) hari kerja berikutnya berdasarkan kesepakatan nasabah atau perwakilan nasabah dan bank.

Kesepakatan antara nasabah atau perwakilan nasabah dengan bank yang dihasilkan dari proses mediasi dituangkan dalam akta kesepakatan yang ditandatangani oleh nasabah atau perwakilan nasabah dan bank. Konsekuensi yuridis setelah akta mediasi ditandatangani oleh para pihak, maka bank wajib melaksanakan hasil penyelesaian sengketa perbankan antara nasabah dengan bank yang telah disepakati dan dituangkan dalam akta kesepakatan. Di samping itu bank juga wajib mempublikasikan adanya sarana alternatif penyelesaian sengketa di bidang perbankan dengan cara mediasi kepada nasabah.

Mediasi perbankan syariah teknis diatur melalui Surat Edaran No. 8/14/DPNP tentang Mediasi Perbankan yang ditujukan kepada semua bank dan nasabah bank di Indonesia. Cara-cara penyelesaian di atas dapat dikatakan sangat tepat dan bijaksana untuk tetap mempertahankan hubungan kerjasama antara bank dengan 
nasabahnya, cara tersebut tidak dijumpai penyelesaian dengan mengajukan gugatan ke pengadilan atau bahkan melakukan eksekusi selama jalan penyelesaian secara non litigasi masih memungkinkan untuk dilaksanakan di dalam dunia perbankan. Hal ini berarti bahwa jika debitur pembiayaan syariah wanprestasi dan penyelesaiannya di mana sebagai lembaga perbankan langkah-langkah penyelesaian juga didasarkan atas prinsip-prinsip perbankan, bukan didasarkan atas langkah cepat jika debitur wanprestasi maka bank mengambil langkah cepat untuk mengamankan kreditnya dengan menjual lelang barang jaminan.

Penyelesaian sengketa pada bank syariah telah terdapat suatu lembaga penyelesaian non litigasi secara kelembagaan muncul pada tahun 1991, yakni dengan berdirinya Bank Muamalah Indonesia (BMI). BMI merupakan bank umum pertama yang mempunyai niatan dan tindakan untuk menerapkan prinsip syariah dalam kegiatan operasionalnya. Di tahun 1997 saat Indonesia mengalami krisis keuangan yang berdampak pada terjadinya krisis perbankan banyak bank-bank komersial yang bangkrut dan berakhir dengan likuidasi. Sementara BMI pada waktu itu masuk dalam kategori bank sehat yang terlihat dengan rendahnya negative spread dan minimnya pembiayaan bermasalah (nonperforming finance). Karena BMI masuk dalam kategori bank yang sehat, maka hanya diwajibkan membuat laporan perihal kegiatan usahanya. Sukses BMI melewati krisis menimbulkan keyakinan bahwa bank berdasarkan prinsip syariah mempunyai keunggulan dibanding dengan bank yang mendasarkan operasionalnya berdasarkan sistem bunga (interest based).

Perbankan syariah sebagai lembaga bisnis tentu saja tidak luput dari potensi sengketa. Pelaksanaan pembiayaan dalam operasional perbankan syariah berpotensi menimbulkan keberatan-keberatan dari pihak bank maupun nasabah yang berakhir dengan munculnya sengketa di antara mereka. Untuk itu, maka perlu adanya sebuah lembaga hukum di luar pengadilan yang 
mampu menjembatani proses tanggal 24 Desember 2003 nama penyelesaian sengketa, sehingga terjadinya ketidakseimbangan dalam masyarakat bisnis dapat dikembalikan pada keadaan semula (restitutio in integrum).

Dalam berbagai pertemuan yang disponsori oleh Majelis Ulama Indonesia (MUI) akhirnya disepakati berdirinya Badan Arbitrase Muamalah Indonesia (BAMUI) tanggal 21 Oktober 1993 atau bertepatan tanggal 05 Jumadil Awal 1414 H. BAMUI didirikan dalam bentuk badan hukum Yayasan melalui akta Notaris Yudo Paripurno, Nomor 175 tanggal 21 Oktober 1993. Kemudian selama kurang lebih 10 (sepuluh) tahun BAMUI menjalankan perannya, dan dengan pertimbangan bahwa anggota pembina dan pengurus BAMUI sudah banyak yang meninggal dunia, juga bentuk badan hukum yayasan sebagaimana diatur dalam UndangUndang Nomor 16 Tahun 2001 tentang Yayasan sudah tidak sesuai dengan kedudukan BAMUI tersebut, maka atas keputusan rapat Dewan Pimpinan Majels Ulama Indonesia Nomor : Kep-09/MUI/XII/2003 BAMUI diubah menjadi Badan Arbitrase Syariah Nasional (BASYARNAS) yang sebelumnya direkomendasikan dari hasil RAKERNAS MUI pada tanggal 2326 Desember 2002. BASYARNAS merupakan badan yang berada di bawah MUI dan merupakan perangkat organisasi MUI.

BASYARNAS merupakan arbitrase institusional khusus yang dapat dijadikan sebagai alternatif forum untuk menyelesaikan sengketa di bidang ekonomi syariah antara lain sengketa perbankan syariah. Institusi ini diperkuat oleh Dewan Syariah Nasional Majelis Ulama Indonesia (DSN-MUI) dengan fatwa Nomor 53/DSN-MUI/III/2006. Prosedur beracara dalam proses pemeriksaan sengketa di BASYARNAS ini telah ditetapkan oleh institusi tersebut yang pada hakikatnya tidak jauh berbeda dengan mekanisme beracara di Pengadilan Umum ataupun di Pengadilan agama sebagaimana diatur dalam HIR/RBg, serta dalam Undang-Undang Nomor 7 Tahun 1989 tentang Peradilan Agama 
sebagaimana telah diubah dengan Undang-Undang Nomor 3 Tahun 2006. Prosedur beracara di BASYARNAS juga hampir sama dengan ketentuan yang tertuang dalam Undang - Undang Nomor 30 Tahun 1999 tentang Arbitrase dan Alternatif Penyelesaian Sengketa.

\section{Simpulan}

Karakteristik pembiayaran ijarah multijasa adalah mengambil manfaat dengan jalan pengganti. Pembiayaran ijarah multijasa tidak hanya dituntut untuk menghasilkan keuntungan melalui setiap transaksi komersial saja, tetapi juga dituntut untuk mengimplementasikan nilainilai syariah yang sesuai dengan Al-Qur`an dan Hadist.

Kriteria wanprestasi pada pembiayaan ijarah multi jasa dan upaya penyelesaiannya adalah apabila salah satu tidak memenuhi kewajiban dalam akad, penyelesaian wanprestasi dalam perbankan syariah dengan mediasi atau melalui BASYARNAS

\section{Daftar Pustaka}

Afandi, Yazid. (2009) Fiqh Muamalah dan Impelementasinya Dalam Lembaga Keuangan Syariah, Yogyakarta: Logung Pustaka.

Antonio, Muhammad Syafi'i. (2001) Bank Syariah dari Teori dan Praktik, Jakarta: Gema Insani.

Ascarya. (2001) Akad \& Produk Bank Syari'ah, Jakarta: Rajawali Pers.

Djamil, Fathurrahman. (2013) Penerapan Hukum Perjanjian Dalam Transaksi di Lembaga Keuangan Syariah, Jakarta: Sinar Grafika.

Goodpaster, Garry. (1995) Arbitrase di Indonesia, Jakarta: Ghalia Indonesia.

Harahap, Yahya. (1998) Segi-segi Hukum Perjanjian, Bandung: Alumni.

Hirsanuddin. (2008) Hukum Perbankan Syariah di Indonesia, Yogyakarta: Genta Press.

Ismail. (2011) Perbankan Syariah, Jakarta: Kencana Prenada Media Group.

Marzuki, Peter Mahmud. (2006) Penelitian Hukum, Jakarta: Kencana Prenada Media Group. 
Muhammad, Abdulkadir. (2004) Hukum Perikatan, Bandung: Alumni.

Muhammad, Rifki. (2008) Akuntansi Keuangan Syariah (Konsep dan implementasi PSAK Syariah), Yogyakarta: P3EI.

Saeed, Abdullah. (1996) Islamic Banking and Interest a Study of The Prohibition of riba and Comtempory Interpretation, E.J BriilNew York-Koln.

Shomad, Abd. (2012) Hukum Islam, Penormaan Prinsip Syariah Dalam Hukum Indonesia, Jakarta: Kencana Prenada Media Group.

Sjahdeini, Sutan Remy. (1999) Perbankan Islam dan Kedudukannya dalam Tata Hukum Perbankan Indonesia, Jakarta: Pustaka Utama Grafiti.

Subekti. (2004) Hukum Perjanjian, Jakarta: Intermasa,.

Suhrawardi, (2000), Hukum Ekonomi Islam, Jakarta: Sinar Grafika.

Suma, Muhammad Amin. (2002) Ekonomi Syariah Sebagai Alternatif Sistem Ekonomi Konvensional, Jurnal Hukum Bisnis, XX.

Sumitro, Warkum. (2002) Asas-asas Perbankan Islam dan Lembaga Terkait BMI \& Takaful Di Indonesia, Raja Grafindo Persada, Jakarta.
Usanti, Trisadini P. (2013) Transaksi Bank Syariah, Jakarta: Bumi Aksara.

Usman, Rachmadi. (2001) Aspekaspek Hukum Perbankan di Indonesia, Jakarta: Gramedia Pustaka Utama. . (2008) Produk dan Akad Perbankan Syariah, Citra Aditya Bakti, Bandung. 